\title{
Dynamic kinetic resolution of $\alpha$-bromoesters containing lactamides as chiral auxiliaries
}

\author{
Alessandra Ammazzalorso, Rosa Amoroso, Giancarlo Bettoni,* Barbara De Filippis, \\ Letizia Giampietro, Cristina Maccallini, and Maria Luisa Tricca \\ Department of Drug Sciences, University “G. D’Annunzio”, Chieti 66100, Italy \\ E-mail: bettoni@unich.it
}

\section{Dedicated to Professor Vincenzo Tortorella in the occasion of his "Fuori Ruolo" status}

(received 31 Dec 03; accepted 12 May 04; published on the web 16 May 04)

\begin{abstract}
The conversion of racemic $\alpha$-bromobutanoic acid into the corresponding esters with amides of (S)-lactic acid as chiral auxiliaries was examinated. Displacement of the bromine with 4chlorophenoxide, under suitable reaction conditions, was found to proceed with good to high diastereoselectivity to give 4-(chlorophenoxy)butanoyl esters. After hydrolysis, the $(R)$ enantiomer of antilipidemic 2-(4-chlorophenoxy)butanoic acid was obtained.
\end{abstract}

Keywords: Lactamides, dynamic kinetic resolution, asymmetric synthesis, analogues of clofibrate

\section{Introduction}

Dynamic kinetic resolution (DKR) is a method to obtain chiral compounds from racemic ones in more than $50 \%$ yields. ${ }^{1}$ The requisite for an effective DKR is the epimerization of substrates prior a reaction in which significant differences in rates between the two isomers exist; in this situation, the slower reacting isomer is converted into the faster one in situ, with theoretically quantitative conversion of the starting material into a single isomer of product.

Among different methods to achieve DKR, extensive studies were carried out on nucleophilic substitution of $\alpha$-halocarboxylic acid derivatives containing a chiral auxiliary in the carboxylic moiety; racemization of labile chiral center in $\alpha$-position to the carbonyl, induced by additives such as polar solvent, bases or halide salts, allows to obtain high asymmetric induction through a dynamic kinetic resolution process. ${ }^{2}$

We applied this methodology to the preparation of chiral 2-aryloxyacid analogues of antilipidemic drug clofibrate, which show different biological activities depending to the stereochemistry; ${ }^{3}$ our synthesis was focused on diastereoselective nucleophilic substitution of 
sodium 4-chlorophenoxide with configurationally labile $\alpha$-bromocarboxylic esters or amides containing the chiral auxiliaries (R)-pantolactone ${ }^{4}$ and (S)-4-isopropyl-1,3-oxazolidin-2-one. ${ }^{5}$ The reaction proceeds with preferential formation of the isomer with $(S)$-configuration to the stereocenter in a to the carbonyl.

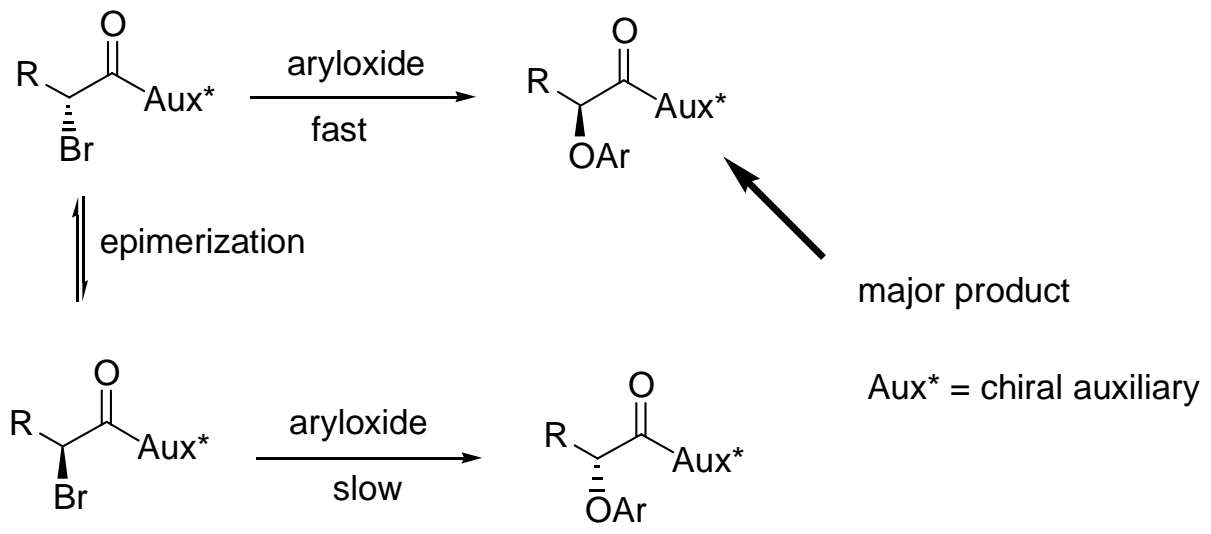

\section{Scheme 1}

Continuing our research on DKR processes, we also developed a stereoselective esterification of rac-ibuprofen with amides of (S)-lactic acid, in the presence of dicyclohexylcarbodiimide (DCC) and 4-dimethylaminopyridine (DMAP). ${ }^{6}$ We envisaged that the same lactamides could be useful as chiral auxiliaries in the above substitution reaction of $\alpha$ bromoacid derivatives. In this paper we present our investigation in this line.

\section{Results and Discussion}

The key feature of the procedure herein described is the $\mathrm{S}_{\mathrm{N}} 2$ reaction of configurationally labile bromosters with an aryloxide; the stereochemistry of products is governed by the amides of $(S)$ lactic acid (S)-1a-c (Figure 1) placed in the carboxylic moiety.

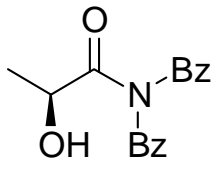

(S)-1a

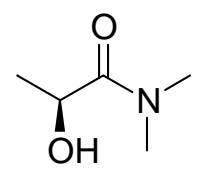

$(S)-\mathbf{1 b}$<smiles>CC(O)C(=O)N1CCCC1</smiles>

$(S)-1 c$

Figure 1

The chiral auxiliaries were readily synthesized according to the literature procedures by simple aminolysis of (S)-ethyl lactate ${ }^{7}$ or $(S)$-lactic acid $^{8}$ with a slight excess of dibenzylamine, dimethylamine and pyrrolidine, and purified through distillation or recrystallization. Alternatively, the synthesis of amide (S)-1c was performed under Weinreb amidation conditions, 
by stirring (S)-ethyl lactate with pyrrolidine, in the presence of equimolar amount of trimethylaluminium; the function of the catalyst is to generate dimethylaluminium amides that react in a relatively short time with ethyl lactate. ${ }^{9}$

The lactamide esters of the $\alpha$-bromobutanoyc acid $(R, S)$-2a-c and $(S, S)$-2a-c were prepared via base-catalyzed addition of (S)-1a-c to the racemic 2-bromobutanoyl chloride, in $\mathrm{CH}_{2} \mathrm{Cl}_{2}$ at $20{ }^{\circ} \mathrm{C}$; GC and ${ }^{1} \mathrm{H}$ NMR investigations showed clearly that in each case approximately equimolar mixtures of diastereoisomers were obtained in good chemical yields.

In order to understand the source of asymmetric induction in nucleophilic substitutions of $\alpha$ bromoesters, we carried out reactions of 2a-c with 4-chlorophenoxide, preformed from 4chlorophenol and sodium, in THF solutions containing triethylamine and catalytic amount of $n$ hexylammonium iodide, at $0{ }^{\circ} \mathrm{C}$ and $60{ }^{\circ} \mathrm{C}$ (Scheme 2). Asymmetric induction was observed in each case since non-equivalent mixtures of the two diastereoisomers of products $(R, S)-\mathbf{3 a - c}$ and $(S, S)-3 a-c$ were achieved with excellent chemical yields.

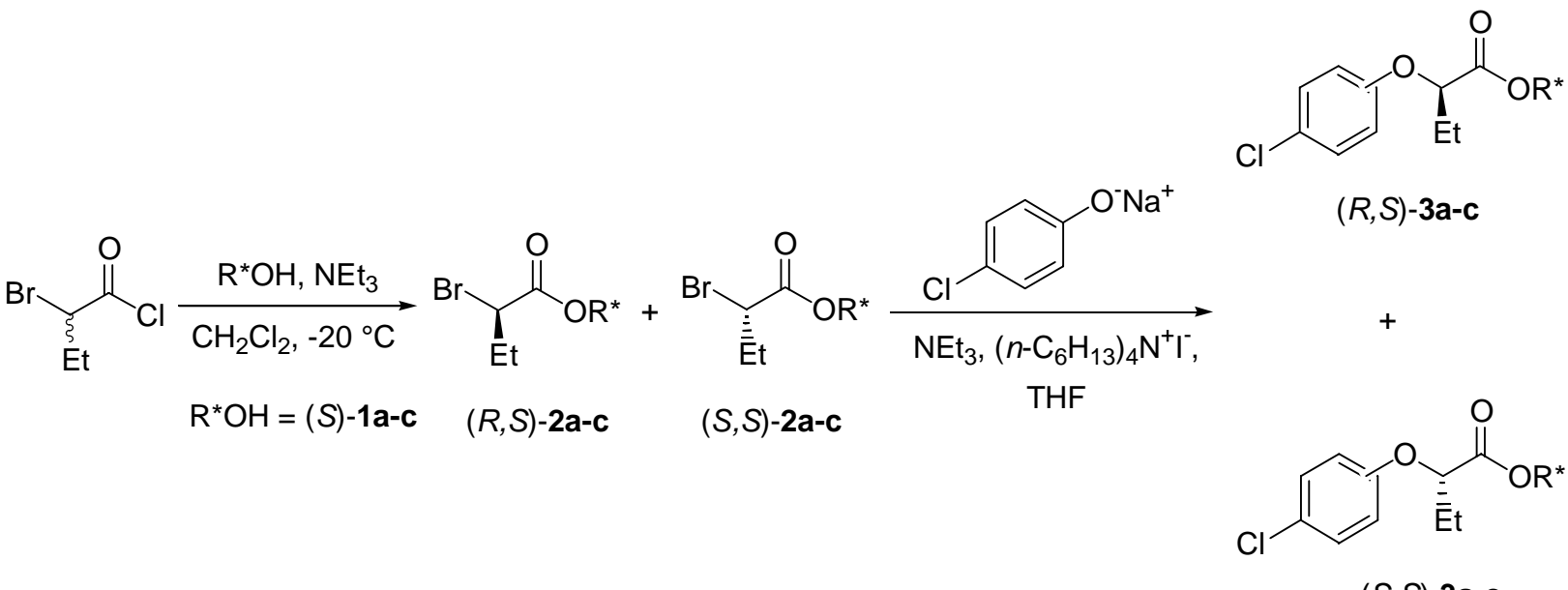

\section{Scheme 2}

With regard to the stereochemistry, variation of the temperature and structural features of the chiral auxiliary were found to influence the diastereoselectivities of these substitution reactions (Table 1). Within the same starting compound, increase of temperature (from $0{ }^{\circ} \mathrm{C}$ to $60{ }^{\circ} \mathrm{C}$ ) leads to a reduction of diastereomeric ratios (entries 2, 4 and 6). Considerable improvement of selectivity was observed with dimethyllactamide (entry 3) compared to dibenzyllactamide (entry 1); the best diastereomeric ratio of $98: 2$ was obtained with the sterically hindered pyrrolidinyllactamide at $0{ }^{\circ} \mathrm{C}$ (entry 5). We rationalise that the pathway of asymmetric induction is determined by a dynamic kinetic resolution process, in which the epimerization to the $\alpha$ carbon of compounds $\mathbf{2 a - c}$, promoted by $\mathrm{NEt}_{3}$ and $n$-hexylammonium iodide, is sufficiently fast respect to the rate of $S_{N} 2$. Under these conditions, the product ratios are determined by the differences in diastereomeric transition states energies for the substitution reactions with phenoxide. 
Table 1. Diastereoselective $\mathrm{S}_{\mathrm{N}} 2$ reaction of bromoesters 2a-c

\begin{tabular}{ccccccc}
\hline Entry & Reactant & Auxiliary & $\begin{array}{c}\text { Temp } \\
\left({ }^{\circ} \mathrm{C}\right)\end{array}$ & $\begin{array}{c}\text { Time } \\
(\mathrm{h})\end{array}$ & $\begin{array}{c}\text { Yield of } \mathbf{3} \\
(\%)\end{array}$ & $\begin{array}{c}\text { Diastereomeric } \\
\text { ratios of } \mathbf{3}^{\mathbf{a}}\end{array}$ \\
\hline 1 & $(S)-\mathbf{2 a}$ & $(S)$-dibenzyl & 0 & 4 & 89 & $80: 20$ \\
2 & $(S)-\mathbf{2 a}$ & lactamide & 60 & 1 & 99 & $70: 30$ \\
\hline 3 & $(S)-2 \mathbf{b}$ & $(S)$-dimethyl & 0 & 6 & 99 & $87: 13$ \\
4 & $(S)-\mathbf{2 b}$ & lactamide & 60 & 0.5 & 72 & $80: 20$ \\
\hline 5 & $(S)-\mathbf{2 c}$ & $(S)$-pyrrolidinyl & 0 & 1.5 & 99 & $98: 2$ \\
6 & $(S)-2 \mathbf{c}$ & lactamide & 60 & 0.5 & 99 & $88: 2$ \\
\hline
\end{tabular}

${ }^{a}$ The diastereomeric ratios of 3a-c were determined by means of ${ }^{1} \mathrm{H}$ NMR data, through integration of the signals related to their stereogenic centers and methyl groups.

The stereochemistry of the major 4-chlorophenoxyesters was elucidated using the 98:2 diastereomeric mixture of $\mathbf{3 c}$ (Table 1, entry 5) chosen as a representative case. Hydrolysis with $\mathrm{LiOH}$ in $\mathrm{THF} / \mathrm{H}_{2} \mathrm{O}^{10}$ at room temperature gave the optically active $(R)$-4(chlorophenoxy)butanoic acid (R)-4 in high yield, without racemization (Scheme 3).<smiles>[R2]OC(=O)[C@H]([Z1])Oc1ccc(Cl)cc1</smiles>

$(R, S)-3 c$<smiles>CC[C@H](Oc1ccc(Cl)cc1)C(=O)O</smiles>

$(R)-4$

98:2 d.r.

\section{Scheme 3}

This $(R)$-acid is a chiral analogue of clofibrate and exhibits higher anti-aggregatory activity, ${ }^{11}$ lower miotonic effects ${ }^{12}$ and hepatocarcinogenicity ${ }^{13}$ compared to the corresponding $(S)$ enantiomer. The specific rotation of $(R)-4$, compared with the literature values, showed it to be essentially pure. The $(S)$-chiral auxiliary was recovered in enantiomerically pure form. The major products of other mixtures are assumed to have the same $(R)$-stereochemistry.

In conclusion, we have applied a stereospecific synthesis of a $(R)$-chiral analogue of clofibrate via dynamic kinetic resolution, using amides derived from lactic acid as novel chiral auxiliaries. Further applications of this methodology to various $\alpha$-substituted- $\alpha$-bromoacids and other lactamides are under investigation. 


\section{Experimental Section}

General Procedures. Melting points were determined on a Electrothermal IA 9100 apparatus and are uncorrected. Optical rotations were measured on a Perkin Elmer model 241 polarimeter. The infrared spectra were recorded on a FT-IR 1600 Perkin Elmer spectrometer. The NMR spectra were run at $300 \mathrm{MHz}$ in $\mathrm{CDCl}_{3}$ solution on a Varian spectrometer; chemical shift ( ) are reported in ppm. Microanalyses were carried out with an Eurovector Euro EA 3000 model analyzer and the analytical results are within $0.4 \%$ of the theoretical values. GC analyses were run on an autosystem GC Perkin Elmer apparatus using a fused silica capillary column (30 m, $0.53 \mathrm{~mm}$ ID), SPB-5 Supelco. Commercial reagents were used as received from Aldrich. THF was distilled from sodium/benzophenone.

\section{Typical procedure for the reaction of rac-2-bromobutanoyl chloride with $(S)$-lactamides}

To a dried and cooled $\left(-20^{\circ} \mathrm{C}\right) \mathrm{CH}_{2} \mathrm{Cl}_{2}$ solution $(40 \mathrm{~mL})$ of $(S)$-lactamide $1(9.0 \mathrm{mmol})$ and triethylamine (1.88 mL, $13.5 \mathrm{mmol}$ ), 2-bromobutanoyl chloride (2.16 g, $11.7 \mathrm{mmol})$ in $\mathrm{CH}_{2} \mathrm{Cl}_{2}$ $(5 \mathrm{~mL})$ was added dropwise, under $\mathrm{N}_{2}$ atmosphere. The mixture was stirred at $-20{ }^{\circ} \mathrm{C}$ for $10 \mathrm{~min}$. After quenching with a saturated aqueous solution of $\mathrm{NH}_{4} \mathrm{Cl}(30 \mathrm{~mL})$, the mixture was extracted with $\mathrm{CH}_{2} \mathrm{Cl}_{2}(3 \times 30 \mathrm{~mL})$ and washed with brine $(2 \times 50 \mathrm{~mL})$. The organic phase was dried over $\mathrm{Na}_{2} \mathrm{SO}_{4}$ and the solvent evaporated at reduced pressure. The equimolar diastereomeric mixture of 2-bromoesters 2 was used as such in the following reaction of substitution.

(1S)-2-(Dibenzylamino)-1-methyl-2-oxoethyl (2R,S)-2-bromobutanoates $(R, S)$-2a and (S,S)(2a). Equimolar mixture, oil, $2.711 \mathrm{~g}, 72 \%$ yield; IR (KBr) 2974,2927, 1820, 1743, $1661 \mathrm{~cm}^{-1}$; ${ }^{1} \mathrm{H}$ NMR $\left(\mathrm{CDCl}_{3}\right): \delta 1.06$ and 1.08 (both t, $3 \mathrm{H}, \mathrm{J}=7.5 \mathrm{~Hz}, \mathrm{~J}=7.2 \mathrm{~Hz}, \mathrm{CH}_{3} \mathrm{CH}_{2}$ ), 1.45 and 1.49 (both d, $3 \mathrm{H}, \mathrm{J}=6.6 \mathrm{~Hz}, \mathrm{~J}=6.6 \mathrm{~Hz}, \mathrm{CH}_{3} \mathrm{CHCON}$ ), 2.01-2.25 (m, 2H, $\mathrm{CH}_{3} \mathrm{CH}_{2}$ ), 4.19-4.53 (m, $\left.4 \mathrm{H}, \mathrm{CH}_{2} \mathrm{NCH}_{2}\right), 4.78(\mathrm{dd}, 1 \mathrm{H}, \mathrm{J}=3.9 \mathrm{~Hz}, \mathrm{~J}=14.7 \mathrm{~Hz}, \mathrm{CHBr}), 5.46(\mathrm{dq}, 1 \mathrm{H}, \mathrm{J}=6.6 \mathrm{~Hz}, \mathrm{~J}=$ $6.6 \mathrm{~Hz}, \mathrm{CH}_{3} \mathrm{CHCON}$ ), 7.12-7.61 (m, $10 \mathrm{H}$, aromatic). Anal. Calcd. For $\mathrm{C}_{21} \mathrm{H}_{24} \mathrm{BrNO}_{3}$ (418.324): C, 60.29; H, 5.78; N, 3.35. Found: C, 60.25; H, 5.80; N, 3.30.

(1S)-2-(Dimethylamino)-1-methyl-2-oxoethyl (2R,S)-2-bromobutanoates $(R, S)-2 \mathrm{~b}$ and $(S, S)$ (2b). Equimolar mixture, oil, $1.796 \mathrm{~g}, 75 \%$ yield; IR (KBr) 2974,2938, 1740, $1644 \mathrm{~cm}^{-1} ;{ }^{1} \mathrm{H}$ $\operatorname{NMR}\left(\mathrm{CDCl}_{3}\right)$ : $\delta$ 1.02-1.09 (m, $1 \mathrm{H}, \mathrm{CH}_{3} \mathrm{CH}_{2}$ ), 1.46 and 1.47 (both d, $3 \mathrm{H}, \mathrm{J}=6.6 \mathrm{~Hz}, \mathrm{~J}=6.6 \mathrm{~Hz}$, $\mathrm{CH}_{3} \mathrm{CHCON}$ ), $1.93-2.22\left(\mathrm{~m}, 2 \mathrm{H}, \mathrm{CH}_{3} \mathrm{CH}_{2}\right.$ ), 3.07 and 3.08 (both s, $6 \mathrm{H}, \mathrm{CH}_{3} \mathrm{NCH}_{3}$ ), 4.17-4.30 (m, $1 \mathrm{H}, \mathrm{CHBr}), 5.44\left(\mathrm{dq}, 1 \mathrm{H}, \mathrm{J}=6.6 \mathrm{~Hz}, \mathrm{~J}=6.6 \mathrm{~Hz}, \mathrm{CH}_{3} \mathrm{CHCON}\right)$. Anal. Calcd. For $\mathrm{C}_{9} \mathrm{H}_{16} \mathrm{BrNO}_{3}$ (266.132): C, 40.62; H, 6.06; N, 5.26. Found: C, 40.58; H, 6.04; N, 5.27.

(1S)-1-Methyl-2-oxo-2-(1-pyrrolidinyl)ethyl (2R,S)-2-bromobutanoates $(R, S)-2 \mathrm{c}$ and $(S, S)$ (2c). Equimolar mixture, oil, $2.129 \mathrm{~g}, 81 \%$ yield; IR (KBr) 2973, 1741, $1656 \mathrm{~cm}^{-1} ;{ }^{1} \mathrm{H}$ NMR $\left(\mathrm{CDCl}_{3}\right): \delta 1.08\left(\mathrm{dt}, 3 \mathrm{H}, \mathrm{J}=7.5 \mathrm{~Hz}\right.$ and $\left.7.2 \mathrm{~Hz}, \mathrm{CH}_{3} \mathrm{CH}_{2}\right), 1.48(\mathrm{dd}, 3 \mathrm{H}, \mathrm{J}=6.6 \mathrm{~Hz}, \mathrm{~J}=6.6 \mathrm{~Hz}$, $\mathrm{CH}_{3} \mathrm{CHCON}$ ), 1.51-2.22 (m, 6H, $\mathrm{CH}_{3} \mathrm{CH}_{2}$ and $\left.\mathrm{NCH}_{2}\left(\mathrm{CH}_{2}\right)_{2}\right), 3.33-3.68\left(\mathrm{~m}, 4 \mathrm{H}, \mathrm{CH}_{2} \mathrm{NCH}_{2}\right.$ ), 4.19-4.30 (m, 1H, CHBr), 5.25 (dq, $1 \mathrm{H}, \mathrm{J}=6.6 \mathrm{~Hz}, \mathrm{~J}=6.6 \mathrm{~Hz}, \mathrm{CH}_{3} \mathrm{CHCON}$ ). Anal. Calcd. For $\mathrm{C}_{11} \mathrm{H}_{18} \mathrm{BrNO}_{3}$ (292.17): C, 45.22; H, 6.21; N, 4.79. Found: C, 45.18; H, 6.20; N, 4.78. 
Typical procedure for the reaction of (S)-lactamide-2-bromoesters with 4-chlorophenoxide Sodium 4-chlorophenoxide was preformed by adding a solution of 4-chlorophenol (140 mg, $1.1 \mathrm{mmol})$ to a stirred suspension of sodium $(23 \mathrm{mg}, 1.0 \mathrm{mmol})$ in dry THF $(10 \mathrm{~mL})$, at room temperature under nitrogen. The resulting solution, eventually preheated, was then added dropwise to a solution of bromoesters $3(1.0 \mathrm{mmol}$ in $6 \mathrm{~mL}$ of dry THF) and stirred until completion of reaction. After quenching with a saturated aqueous solution of $\mathrm{NaCl}(10 \mathrm{~mL})$, the mixture was extracted with $\mathrm{CH}_{2} \mathrm{Cl}_{2}(3 \times 15 \mathrm{~mL})$. The organic phase was washed with $\mathrm{H}_{2} \mathrm{O}(3 \mathrm{x}$ $15 \mathrm{~mL}$ ), dried over $\mathrm{Na}_{2} \mathrm{SO}_{4}$ and concentrated at reduced pressure. The residue was purified by column chromatography on silica gel (cyclohexane/ethylacetate 7:3) to give the diastereomeric mixture of 4-chlorophenoxyesters 3. The times, temperatures, yields and diastereomeric ratios are indicated in Table 1. The data below are referred to the reactions with best diastereomeric ratios. The coupling constants in the NMR spectra have been calculated only for major isomer of each mixture.

(1S)-2-(Dibenzylamino)-1-methyl-2-oxoethyl (2R,S)-2-(4-chlorophenoxy) butanoates (R,S)(3a) and (S,S)-(3a). Diastereomeric mixture, oil, $414 \mathrm{mg}, 89 \%$ yield; IR (KBr) 2955, 2864, 1754, $1659 \mathrm{~cm}^{-1} ;{ }^{1} \mathrm{H} \mathrm{NMR}\left(\mathrm{CDCl}_{3}\right): \delta 1.08\left(\mathrm{dt}, 3 \mathrm{H}, \mathrm{J}=7.5 \mathrm{~Hz}, \mathrm{CH}_{3} \mathrm{CH}_{2}\right), 1.43$ and 1.45 (both d, $\left.3 \mathrm{H}, \mathrm{J}=6.6 \mathrm{~Hz}, \mathrm{CH}_{3} \mathrm{CHCON}\right), 1.95-2.07\left(\mathrm{~m}, 2 \mathrm{H}, \mathrm{CH}_{3} \mathrm{CH}_{2}\right), 4.37-4.66\left(\mathrm{~m}, 5 \mathrm{H}, \mathrm{CH}_{2} \mathrm{NCH}_{2}\right.$ and $\left.\mathrm{CH}_{3} \mathrm{CH}_{2} \mathrm{CH}\right), 5.46\left(\mathrm{dq}, 1 \mathrm{H}, \mathrm{J}=6.6 \mathrm{~Hz}, \mathrm{CH}_{3} \mathrm{CHCON}\right), 6.82-7.37$ (m, 14H, aromatic). Anal. Calcd. For $\mathrm{C}_{27} \mathrm{H}_{28} \mathrm{ClNO}_{4}$ (465.968): C, 69.59; H, 6.06; N, 3.01. Found: C, 69.52; H, 6.05; N, 3.02 .

(1S)-2-(Dimethylamino)-1-methyl-2-oxoethyl (2R,S)-2-(4-chlorophenoxy) butanoates $(R, S)$ (3b) and (S,S)-(3b). Diastereomeric mixture, oil, $311 \mathrm{mg}, 99 \%$ yield; IR (KBr) 2975, 2938, 2893, 1754, $1666 \mathrm{~cm}^{-1} ;{ }^{1} \mathrm{H}$ NMR $\left(\mathrm{CDCl}_{3}\right): \delta 1.10\left(\mathrm{dt}, 3 \mathrm{H}, \mathrm{J}=6.9 \mathrm{~Hz}, \mathrm{CH}_{3} \mathrm{CH}_{2}\right), 1.43$ and 1.47 (both d, 3H, J = 6.6 Hz, $\mathrm{CH}_{3} \mathrm{CHCON}$ ), 1.99-2.12 (m, 2H, $\mathrm{CH}_{3} \mathrm{CH}_{2}$ ), 2.94, 2.95, 3.01, 3.02 (each $\left.\mathrm{s}, 6 \mathrm{H}, \mathrm{CH}_{3} \mathrm{NCH}_{3}\right), 4.60\left(\mathrm{~m}, 1 \mathrm{H}, \mathrm{CH}_{3} \mathrm{CH}_{2} \mathrm{CH}\right), 5.42$ (dq, 1H, J 6.6 Hz, $\mathrm{CH}_{3} \mathrm{CHCON}$ ), 6.84-7.26 (m, 4H, aromatic). Anal. Calcd. For $\mathrm{C}_{15} \mathrm{H}_{20} \mathrm{BrClNO}_{4}$ (313.776): C, 57.42; H, 6.42; N, 4.46. Found: C, 57.35; H, 6.41; N, 4.47.

(1S)-1-Methyl-2-oxo-2-(1-pyrrolidinyl)ethyl (2R,S)-(4-chlorophenoxy) butanoates $(R, S)-(3 \mathrm{c})$ and $(S, S)-(3 c)$. Diastereomeric mixture, oil, $336 \mathrm{mg}, 99 \%$ yield; IR (KBr) 2975, 1746, $1652 \mathrm{~cm}^{-}$ ${ }^{1} ;{ }^{1} \mathrm{H} \mathrm{NMR}\left(\mathrm{CDCl}_{3}\right): \delta 1.08\left(\mathrm{dt}, 3 \mathrm{H}, \mathrm{J}=7.5 \mathrm{~Hz}, \mathrm{CH}_{3} \mathrm{CH}_{2}\right), 1.45(\mathrm{dd}, 3 \mathrm{H}, \mathrm{J}=6.6 \mathrm{~Hz}$, $\mathrm{CH}_{3} \mathrm{CHCON}$ ), $1.78-2.10\left(\mathrm{~m}, 6 \mathrm{H}, \mathrm{CH}_{3} \mathrm{CH}_{2}\right.$ and $\mathrm{NCH}_{2}\left(\mathrm{CH}_{2}\right)_{2}, 3.26-3.60\left(\mathrm{~m}, 4 \mathrm{H}, \mathrm{CH}_{2} \mathrm{NCH}_{2}\right)$, 4.44-4.62 (m, 1H, $\left.\mathrm{CH}_{3} \mathrm{CH}_{2} \mathrm{CH}\right), 5.23\left(\mathrm{dq}, 1 \mathrm{H}, \mathrm{J}=6.6 \mathrm{~Hz}, \mathrm{CH}_{3} \mathrm{CHCON}\right), 6.23-7.26(\mathrm{~m}, 4 \mathrm{H}$, aromatic). Anal. Calcd. For $\mathrm{C}_{17} \mathrm{H}_{22} \mathrm{ClNO}_{34}$ (339.814): C, 60.09; H, 6.53; N, 4.12. Found: C, $60.18 ; \mathrm{H}, 6.51 ; \mathrm{N}, 4.13$.

\section{(2R)-2-(4-Chlorophenoxy)butanoic acid (R)-4}

To a solution of $(R, S)-3 \mathbf{c}$ and $(S, S)-3 \mathbf{c}(98: 2$ diastereomeric mixture, $242 \mathrm{mg}, 0.68 \mathrm{mmol})$ in 4:1 $\mathrm{THF} / \mathrm{H}_{2} \mathrm{O}(15 \mathrm{~mL}), \mathrm{LiOH}\left(57 \mathrm{mg}, 1.36 \mathrm{mmol}\right.$ in $15 \mathrm{~mL}$ of $\left.\mathrm{H}_{2} \mathrm{O}\right)$ was added, at $0{ }^{\circ} \mathrm{C}$. After stirring at room temperature overnight, the most of THF was evaporated at reduced pressure. The residue was extracted with $\mathrm{Et}_{2} \mathrm{O}(4 \times 15 \mathrm{~mL})$, acidified with $2 \mathrm{~N} \mathrm{HCl}$ until $\mathrm{pH}=1.0$ and re- 
extracted with $\mathrm{CH}_{2} \mathrm{Cl}_{2}(3 \times 15 \mathrm{~mL})$. The organic phase was dried over $\mathrm{Na}_{2} \mathrm{SO}_{4}$ and the solvent evaporated at reduced pressure to give the $(R)-4$-(chlorophenoxy)butanoic acid $(R)-4$ (208 $\mathrm{mg}$, $0.58 \mathrm{mmol}, 86 \%$ yield) as crude product. Mp 76-78 ${ }^{\circ} \mathrm{C}$; IR $(\mathrm{KBr}) 1706 \mathrm{~cm}^{-1} ;[\alpha]_{\mathrm{D}}{ }^{20}+42.1$ (c $1.3, \mathrm{MeOH}),[\alpha]_{\mathrm{D}}{ }^{20}-41.5(\mathrm{MeOH}){ }^{14}$ for $(S)$-isomer; ${ }^{1} \mathrm{H}$ NMR $\left(\mathrm{CDCl}_{3}\right): \delta 1.07(\mathrm{t}, 3 \mathrm{H}, \mathrm{J}=7.0 \mathrm{~Hz}$, $\left.\mathrm{CH}_{3}\right), 1.83-2.23\left(\mathrm{~m}, 2 \mathrm{H}, \mathrm{CH}_{2}\right), 4.54(\mathrm{t}, 1 \mathrm{H}, \mathrm{J}=7.0 \mathrm{~Hz}, \mathrm{CH}), 6.68-7.40$ (m, 4H, aromatic).

\section{Acknowledgements}

We are grateful to Italian MIUR for financial support.

\section{References}

1. Pellissier, H. Tetrahedron 2003, 59, 8291.

2. Ben, R. N.; Durst, T. J. Org. Chem. 1999, 64, 7700.

3. Esbenshade, T. A.; Kamanna, V. S.; Newman, H. A. I.; Tortorella, V.; Witiak, D. T.; Feller, D. R. Biochem. Pharmacol. 1990, 40, 1263.

4. Ammazzalorso, A.; Amoroso, R.; Bettoni, G.; De Filippis, B. Chirality 2001, 13, 102.

5. Amoroso, R.; Bettoni, G.; De Filippis, B.; Tricca, M. L. Chirality 1999, 11, 483.

6. Ammazzalorso, A.; Amoroso, R.; Bettoni, G.; De Filippis, B.; Giampietro, L.; Pierini, M.; Tricca, M. L. Tetrahedron Lett. 2002, 43, 4325.

7. Crear, X.; Hatoum, H. N.; Barton, A.; Aldridge, T. E. J. Org. Chem. 1992, 57, 1887.

8. Fein, M. L.; Filachione, E. M. J. Amer. Chem. Soc. 1953, 75, 2097.

9. Basha, A.; Lipton, M.; Weinreb, S. M. Tetrahedron Lett. 1977, 48, 4171.

10. Koh, K.; Durst, T. J. Org. Chem. 1994, 59, 4683.

11. Feller, D. R.; Kamanna, V. S.; Newman, H. A. I.; Romstedt, K. J.; Witiak, D. T.; Bettoni, G.; Bryant, S. H.; Conte-Camerino, D.; Loiodice, F.; Tortorella, V. J. Med. Chem. 1987, 30, 1265.

12. Bettoni, G.; Loiodice, F.; Tortorella, V.; Conte-Camerino, D.; Mambrini, M.; Ferrannini, E.; Bryant, S. H. J. Med. Chem. 1987, 30, 93.

13. Rangwala, S. M.; O’Brien, M. L.; Tortorella, V.; Longo, A.; Loiodice, F.; Noonan, D. J.; Feller, D. R. Chirality 1997, 9, 1263.

14. Bettoni, G.; Ferorelli, S.; Loiodice, F.; Tangari, N.; Tortorella, V.; Gasparrini, F.; Misiti, D.; Villani, C. Chirality 1992, 4, 193. 